\title{
An Overview of the Evolution of Modern Macroeconomic Theories
}

\author{
Zijian Liang $^{1}$ and Michael Silber ${ }^{2}$ \\ 'St. George's School, Vancouver, Canada \\ ${ }^{2}$ Seoul International School, South Korea
}

\section{ABSTRACT}

This paper examines the evolution of macroeconomic theories from the 18th century to present. The manuscript starts off on giving a short analysis on the Great Depression and how it sparked numerous changes in macroeconomic policies. Then, the Classical Economic Theory is introduced and its shortcomings are examined through the Panic of 1873. Next, the paper's focus will shift to a deeper analysis on the causes, impacts, and the recovery of the Great Depression and the effects it had on the United States economy. Keynesianism and the benefits of fiscal policy are introduced and reasons for the rejection of the Classical Economic theory are explained. William Phillips' Phillips Curve is then introduced and connections between Phillips' theory and Keynes' theory are made. Lastly, the paper will examine the effects of monetary policy in the 1970s and the recent Great Recession of 2008. Most importantly, the reasons modern economists like Friedman oppose fiscal policy and Keynesianism are interpreted. From the works of these economists, the central argument of the paper advocates for the fact that we can no longer rely on the Classical Economic theory during times of economic crisis. The modern economy should be observing both Keynesianism and Monetarism; we should be pursuing expansionary fiscal policy during times of downturns and contractionary monetary policy during times of economic boom.

\section{Introduction}

In the 1930s, the world suffered from the worst economic downturn in history known as the Great Depression. Economists conceded that the Great Depression began in the United States on October 24, 1929, when the stock market suddenly crashed as ambitious investors altogether sold approximately 12.9 million shares. Five days later, on October 29, 1929, another 16 million shares were sold as the stock market further collapsed, paralyzing Wall Street investors as the nation never saw such an unprecedented and precipitous financial crisis since its industrialization (Onion et al., 2020, Great Depression History). The unexpected destruction of the world-renown financial sector disintegrated worldwide consumer confidence, and consumption and investment in many countries declined rapidly, leading to reduced levels of output and sharp decreases in the price level. As a result of the massive decreased demand for goods and services, firms were forced to discharge their workers and cut wages on their remaining workers. By 1933, the global gross domestic product had fallen by $26.7 \%$ and the global unemployment rate reached its peak at $24.9 \%$. The United States, however, has suffered even worse with a drop in the real gross domestic product by $30 \%$ and a decline in the price level of 33\% (Pells \& Romer, 2019).

The Great Depression proved to be an essential part of American history; the destructive effects of this unanticipated economic crisis have sparked numerous debates between economists and formed profound changes in major macroeconomic theories. For long, economists depended on Adam Smith's theory of the "Invisible Hand," which for a market economy suggests that there exist invisible forces in an economy that prompt markets to move towards an equilibrium. Individuals should follow their own interests and the economy would eventually "self-correct" 
over time, without the need to accentuate or rely on fiscal and monetary policy (Majaski, 2020). While Smith's theory had been regularly observed in the American economy throughout the 19th century, the Great Depression and the periods of stagflation later observed in the 1970s provoked new insights on the extent to which Smith's theory could be applied to the modern economy.

During the peak of the Great Depression, President Herbert Hoover enacted economic policies with the intention to reduce the severity of the depression, with most of his policies centering around reducing unemployment, continuing production, and opposing direct federal intervention. However, Hoover's response to the Great Depression was generally viewed as limited and unprepared, as he severely underestimated the scope of the depression. Despite the resilient efforts put forth by President Herbert Hoover, none of his policies seemed to bring the economy out of the depression and he was soon trounced by President Franklin D. Roosevelt (Corbett et al., 2014).

Unlike Hoover who was a direct supporter of classical economics, Roosevelt followed advice from economist John Maynard Keynes through his letter "An Open Letter to President Roosevelt" in 1933 that advocated for the establishment of fiscal policy and government programs to combat the Great Depression. Keynes challenged the classical economists, arguing that prices and wages do not always adjust to current economic conditions; therefore, the only solution to the Great Depression is to rely on active fiscal policy to encourage spending. Ultimately, Roosevelt took Keynes' advice and his New Deal Program prospered in repairing the economy. Economists accepted Keynesianism and deemed Keynes as a turning point in the evolution of macroeconomic theory.

However, as time progressed to the 1970s, the United States economy suffered from unprecedented levels of stagflation - simultaneous high levels of inflation and unemployment. It was then economist Milton Friedman accentuated the importance of the Federal Reserve in controlling the nation's money supply, rejecting fiscal policy through the Crowding Out Effect and William Phillips' theory of inflation and unemployment in the long run. The practice of controlling money supply, known as Monetarism, was then widely practiced in the 1980s and beyond by President Ronald Reagan and other monetarists.

Nevertheless, while many economists thought that the Federal Reserve can maximize benefits and promote economic growth, it is not the sole solution to conquering economic catastrophes. As evidenced by the failure of banks to manage mortgages and comply with lending policies, the Great Recession of 2007-2009 proved that Keynesianism and effects of fiscal policy are still very much relevant to the modern economy.

Economists have come to the realization that the global economy is not as simple as what the classical economists had suggested. Simply waiting for prices and wages to adjust to the current economic conditions no longer proved to be a wise choice to mobilize stability in the short run. The modern economy should be observing both Keynesianism and Monetarism; we should be pursuing expansionary fiscal policy during times of downturns and contractionary monetary policy during times of economic boom. When these policies are applied efficiently, the economy will observe immediate short-term effects and stable monetary growth in the long run.

To understand the limitations of the Invisible Hand, and the conditions that led to the Great Depression, we need to first examine the Classical Economic Theory. The focus would then proceed to an analysis of Keynesianism and the benefits and shortcomings of fiscal policy during the Great Depression. Lastly, an analysis of the effects of monetary policy during the 1970s and the recent Great Recession of 2008 will be conducted.

\section{The Classical Economic Theory}

The Classical Economic Theory originated in Britain in the late 18th to early 19th century after Adam Smith's proposal of the "Invisible Hand Theory." Some other founding fathers of this economic theory are Jean-Baptise Say, David Ricardo, James Mill, John Stuart Mill, and Thomas Robert Malthus. In short, the Classical Theory suggests that an economy is better off when individuals follow their self-interest and engage in free trade and free competition (Young, 2020), as Adam Smith once said: 
"Consumption is the sole end and purpose of all production; and the interest of the producer ought to be attended to, only so far as it may be necessary for promoting that of the consumer" (Kilcoyne, 2019).

Classical economists support the claim that any type of government intervention would severely harm the economy and discourage long-run economic growth. When examining the economy as a whole, classical economists believe that when resources are used and exploited efficiently, the economy would always operate at its natural rate/potential output and maintain a static unemployment rate of around 4\%-5\%. Classical economists insist that prices and wages are always flexible and therefore would adjust quickly to any short-run changes in the economy. If the economy is producing below its potential output, prices and wages would fall and production would increase until the economy reaches its potential. Vice versa, if the economy is operating beyond its potential output, inflation will soon set in and prices and wages would rise, decelerating the rate of production and shifting the economy back to its potential output (Willis, 2017). Altogether, these forces in the economy make up the two components that are represented in the most conventionalized and idealistic macroeconomic model: aggregate demand and aggregate supply.

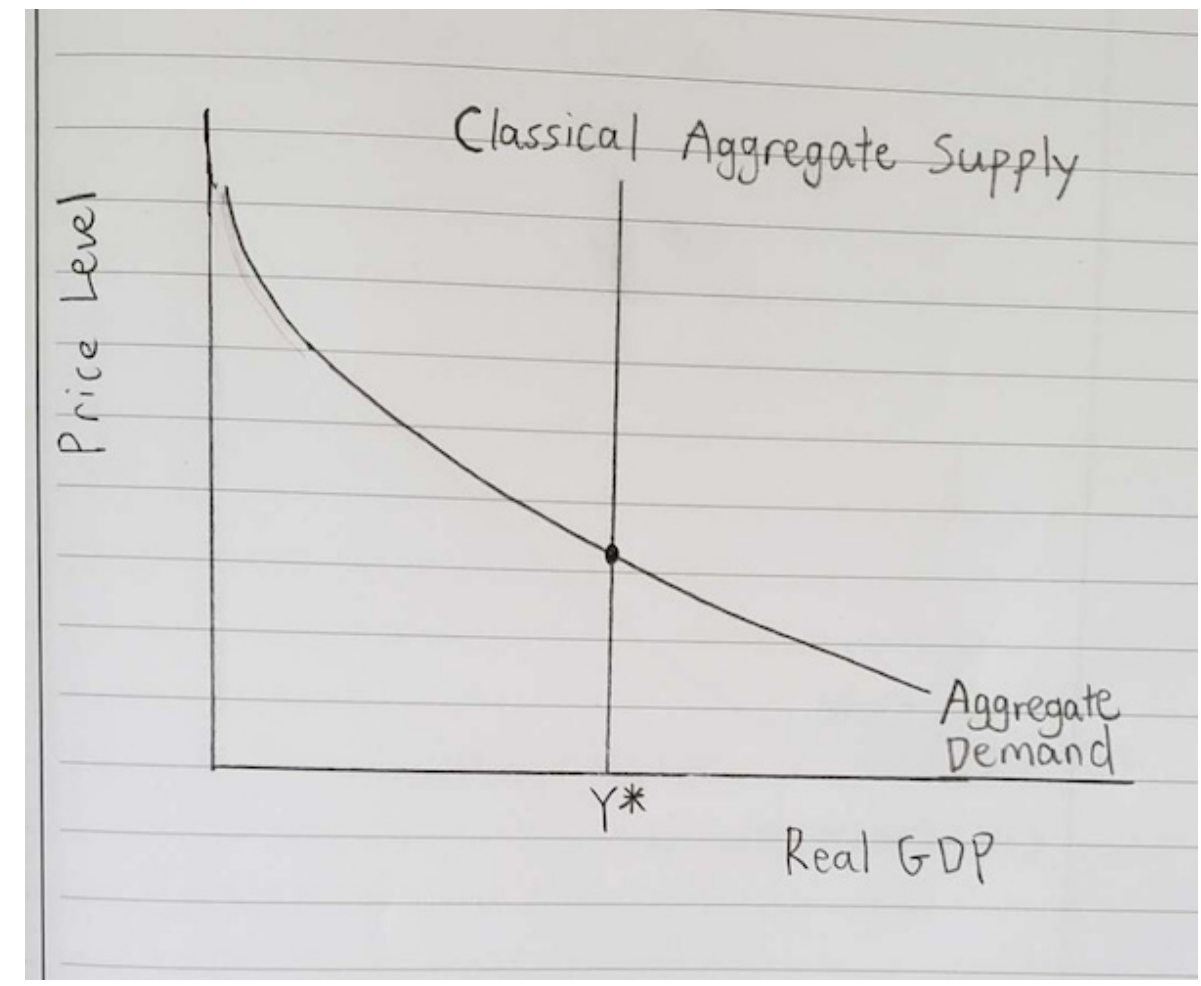

Figure 1: classical economists insist that aggregate supply is vertical; this economy will operate at $\mathrm{Y}^{*}$ in normal circumstances.

Aggregate demand represents the absolute demand for all finished goods and services in the economy at each price level; it comprises consumer spending, investment spending, government expenditures, and net exports. Any major changes in these four components would shift the aggregate demand curve. As shown in figure 1 above, when graphed on a real gross domestic product and price level chart, aggregate demand will always be down sloping from the economic law that there will always be more goods and services demanded at lower price levels than higher price levels. Aggregate supply shows the economy's total output, or the number of goods and services businesses are willing to supply at different price levels. Components of aggregate supply are not fixed, but in the modern economy, changes in taxation, technology, prices, wages, and inflation are known to shift the aggregate supply curve (Kenton, 2020, Aggregate Supply). The shape of the aggregate supply, however, was among the debates of many economists during 
the 19th and 20th centuries. While many view aggregate supply as an upsloping curve that represents a positive relationship between changes in price level and output, classical economists had distinctive interpretations of the aggregate supply curve. For more than a century, classical economists presumed that aggregate supply is vertical, showing no tradeoffs between an economy's output and price level (Pettinger et al., 2019). When graphed the aggregate demand and aggregate supply together, a healthy economy would operate at the intersection of these two curves, known as the macroeconomic equilibrium. The vertical aggregate supply indicates that an economy will always produce at its potential output ( $\mathrm{Y}^{*}$ in Figure 1); therefore, the classical theory indicates that aggregate supply is always fixed and that any short-run changes in the economy will only prompt shifts in aggregate demand.

Undoubtedly, the classical economists brought profound changes to the political and economic systems of many western countries. As the theory was introduced shortly after the Industrial Revolution, it helped many countries to appreciate the importance of the free market economy, in particular, the private ownership of resources. As such, the "classical economic theory helped countries to migrate from monarch rule to capitalistic democracies with selfregulation." This helped many European countries such as Great Britain, France, and the United States gain an immediate advantage in the global economy and became the superpowers in World War One (Young, 2020).

As time progressed through the late 19th century and very early 20th century, the Classical Economic Model was modified to the decision-making process of individuals and firms in the economy. As such, the laws of demand and supply and the rational choice theory were established, marking the fundamentals of microeconomics and the beginning of "Neoclassical Economics." Nevertheless, the economists' approach to the macroeconomy in the western world remained relatively the same: in the case of an economic crisis, the invisible forces in an economy would eventually stimulate it back to its potential output. For instance, during the Panic of 1873, also known as the Long Depression, there was minimal government spending and the government adopted a laissez-faire approach towards the economy. This economic crisis came with several bank and railroad failures. The government announced that it would purchase $\$ 10$ worth of bonds, but they never did, and the high unemployment rate resulted in major labor unrest. The Congress passed a bill in 1874 to print currency to reduce the real value of debts, but President Grant vetoed the bill and campaigned against fiscal policy to correct the economy (Lee, 2008). The economy was eventually able to recover, but it observed several boom and bust cycles in the coming years, which according to classical economists, are natural phenomena. The Panic of 1873 implies that the government expected the Invisible Hand to fix the economy; therefore, it was in their best interest to leave it alone.

The classical economic theory was ultimately challenged by British Economist John Maynard Keynes during the Great Depression. Keynes was a revolutionary economist who influenced new macroeconomic insights that suggest Adam Smith's "Invisible Hand" would not always be effective during a severe economic recession; the economic model was too simple and general to be applied in the many complicated societies. Together, his proposed theories formed Keynesianism, an economic theory that is widely practiced in many economies in the world. 


\section{Keynesianism}

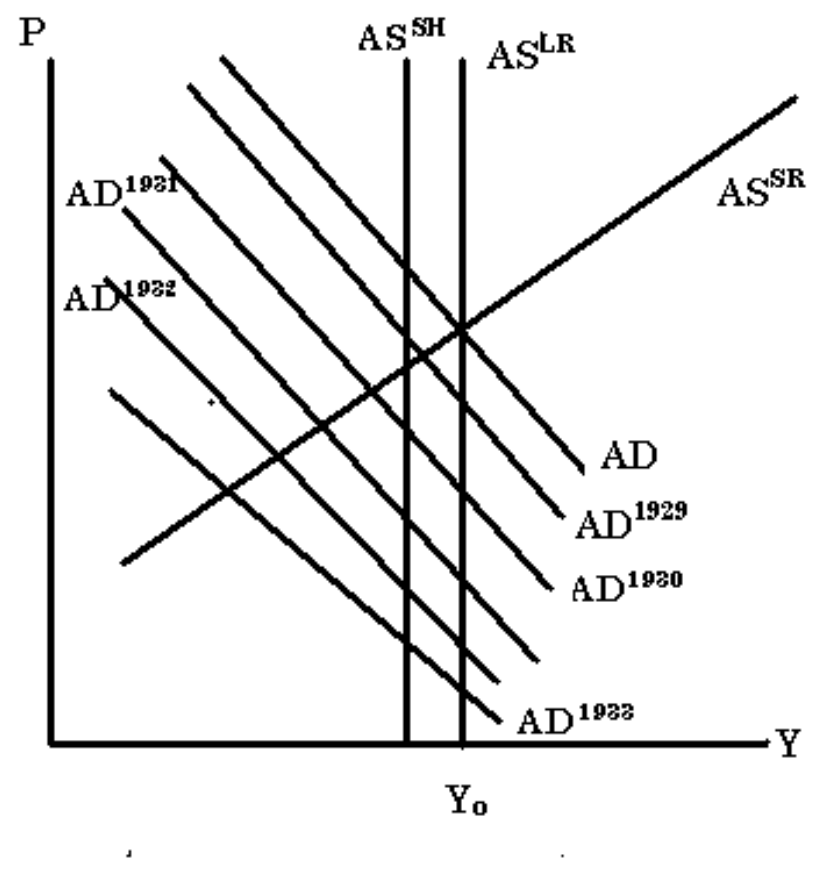

Figure 2: The United States economy can be characterized by a constant leftward shift of aggregate demand during the Great Depression.

In the United States, after the two severe stock market crashes in late 1929 and the failure of over 650 banks, the money supply of the economy was severely reduced, increasing the value of each American Dollar and strictly reducing the amount of loans available for businesses and lenders. As a result, it became costly for businesses lenders to pay back, causing a sharp increase in the national unemployment rate and personal bankruptcies. Over the next few months, consumer confidence decreased throughout the nation, leading to decreased investment in capital and spending on goods and services, shifting aggregate demand to the left as shown in Figure 2. In 1930, the United States began to suffer from the severe Dust Bowl Drought that struck 23 states in the Mid-Atlantic Region, which destroyed many farm fields and cut off the United States' food supply. President Hoover ordered assistance from the American Red Cross, but the drought prolonged and the economy further collapsed. By the end of 1930, the Bank of United States collapsed from a sudden large crowd of withdrawers. The unemployment rate had increased to $8.7 \%$ and prices fell by $6.4 \%$ (Amadeo, 2020, Great Depression Timeline).

At this stage, many major businesses closed down and dismissed a large proportion of its workers. This phenomenon also applied to many other countries such as Brazil, Germany, Great Britain, and France at that time, but the United States began to suffer from the worst of it. According to Figure 2, aggregate demand of the United States economy had significantly fallen by this time, leading to a decreased price level and output. By February of 1931, many American citizens were laid off and had to rely on soup kitchens to feed themselves, which caused massive food riots in Minneapolis, Minnesota. While President Hoover attempted to resolve the massive economic crisis, he established and signed the Revenue Act of 1932 which increased top income taxes to 63\% with the hope to reduce federal deficit and restore business confidence. Much to people's surprise, the Revenue Act of 1932 further counteracted 
aggregate demand throughout the rest of the year, moving the United States economy into a further recession (from AD1932 to AD1933) with an unemployment rate of $23.6 \%$ (Corbett et al., 2014).

Nevertheless, it was at this point that parts of America realized the rate of deflation had slowed down and stabilized, but not the unemployment rate. But according to the classical theory, prices and wages would continue to fall as long as the economy is in a recessionary gap; they would fall until production begins to increase and when consumers regain their purchasing power for consumption and investment. This was clearly not the case in 1933, but the United States continued to shut down banks, increase tax rates, and reduce production with the hope to obtain even lower prices. This caused sustained decreases in aggregate demand, and the United States' economy moved further away from its potential output and was in serious struggle, leading to the termination of President Hoover's responsibilities as a result of the acrid criticisms from the American citizens. Nonetheless, these actions did not further decrease price and wages but rather increased the unemployment rate to $24.9 \%$, leaving the United States' economy in shambles (Pells \& Romer, 2020).

Throughout the four years, John Maynard Keynes carefully observed the world economy as it collapsed, confronting whether the Invisible Hand would automatically correct the economy. After inspecting the situation in the United States, Keynes concluded that in some situations, especially in severe recessions where the economy has severely deviated from its potential output, the Invisible Hand is broken. This motivated Keynes to compose his last major book, The General Theory of Employment, Interest, and Money, where he concluded that aggregate demand determines the price of labor, not the level of employment. As a result, "potential output" that the classical economists commonly referred to was the result of sustained competitiveness in the economy; in other words, if competition decreases in the economy, the economy would shift and settle on a different new long-run equilibrium. Before publishing his book, Keynes announced that his main objective was to challenge classical economic theory.

"I believe myself to be writing a book on economic theory which will largely revolutionize — not I suppose, at once but in the course of the next ten years - the way the world thinks about its economic problems. The difficulty lies, not in the new ideas, but in escaping from the old ones, which ramify, for those brought up as most of us have been, into every corner of our minds" (Keynes, 1936).

Keynes, however, was not entirely opposed to the classical economists. Much like the classical economists, Keynes believed that when the economy is producing beyond or at its potential output, prices and wages are quite flexible: if the economy is experiencing unusually low unemployment and producing beyond its potential, inflation will soon set in, causing immediate upward pressure on prices and wages. and bringing the economy back to its potential. However, as the economy moves into a recessionary gap, prices and wages are no longer flexible and are rather "sticky." Sticky prices and wages indicate that they do not adjust quickly to the current economic situation and in the case of a severe recession, they would stop falling after a certain point. During the Great Depression, people expected that prices and wages would continue to fall to compensate for and counteract the massive levels of unemployment, but they became sticky and stopped falling after the economies entered the severe recession (Kenton, 2018, What Is the Sticky Wage Theory?). According to Keynes, the "Sticky Wage Theory" makes sense and could be simply explained with logic. For instance, if the current standard of living requires workers to receive a minimum wage of $\$ 10$ an hour, workers would only accept to work if they are paid $\$ 10$ or more. However, if wages have already fallen to $\$ 8$, workers would not be willing to accept the job offer, not to mention when wages fall to \$4. This scenario explains the high level of unemployment, where nominal wages fell below people's standard of living. As a result, employers were unwilling to pay workers the wage they demanded, and their only solution was to lay off workers to avoid bankruptcy. Therefore, despite the unemployment compensation and programs President Herbert Hoover attempted to enact, the unemployment rate never shrank.

Assuredly, Keynes' "Sticky Wage Theory" allowed for a new formation of the aggregate supply curve. Keynes insisted that the aggregate supply curve would be upsloping in the short run as the law of supply indicates that more goods and services would be supplied at higher price levels. Yet, in the long run, aggregate supply is not as 
simple as what the classical economists used to believe. For Keynes, the concept of the long run in an economy is much more complicated and uncertain than what most economists previously speculated:

"The long run is a misleading guide to current affairs. In the long run we are all dead" (Keynes, 1936).

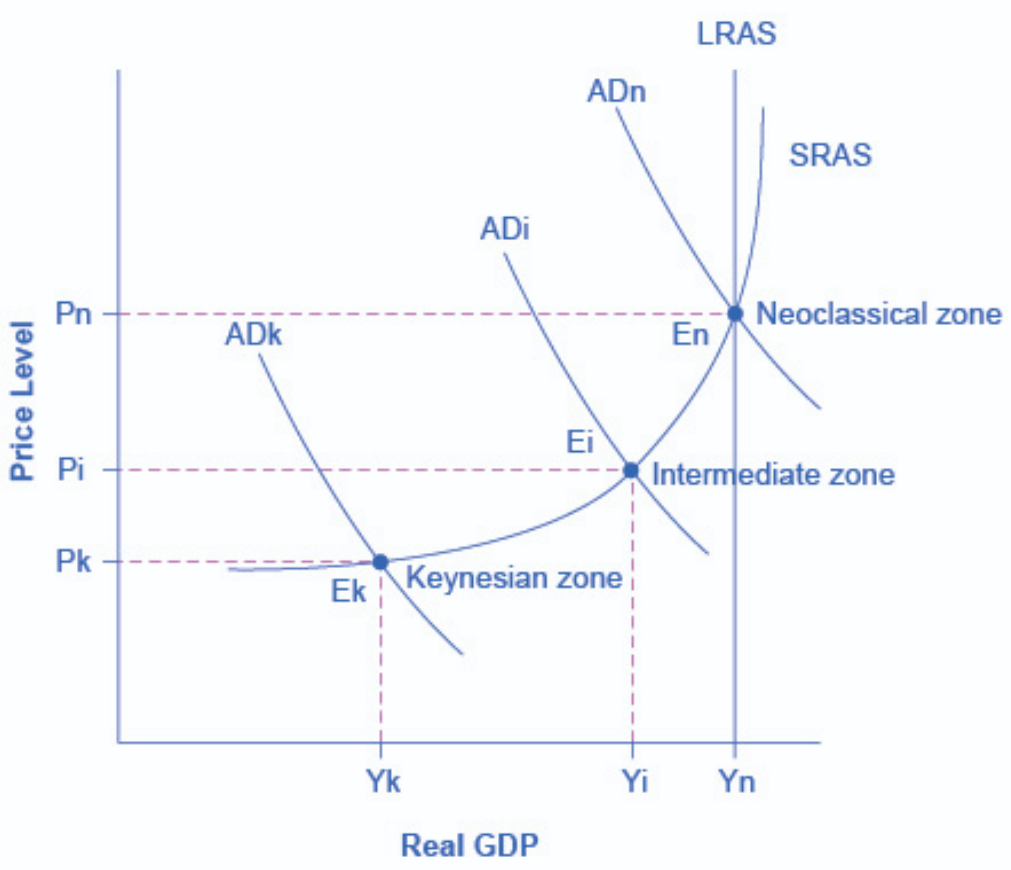

Figure 3: the three parts of the Keynesian aggregate supply curve.

Displayed above, the Keynesian long run aggregate supply curve consists of three ranges: Classical range, intermediary range, and the Keynesian range. The Classical range is in accordance with the classical economists and resembles the economy when it is at its potential or beyond: prices and wages are flexible, so if aggregate demand keeps increasing then the price level would skyrocket while real gross domestic product remains relatively the same. The intermediary range shows an upsloping aggregate supply curve; prices and wages are still somewhat flexible and shifts in aggregate demand from ADn to ADi would change both the economy's output and price level. The Keynesian range, however, was an aspect classical economists could never have predicted; the aggregate supply curve is horizontal, indicating that any changes in an economy's output would not change prices and wages because they became sticky after entering into a recession. As shown in Figure 3 above, the shift of aggregate demand from ADi to ADk results in a very small change in the price level but a large reduction in output, resulting in higher levels of unemployment. Keynes insisted that an economy would be in the intermediary range of the aggregate supply curve once it enters a recession, since the rate at which prices and wages are falling would begin to slow down as aggregate demand continues to fall. In the interim of the Great Depression, the effects of the stock market crash of 1929 moved the United States economy into the intermediary portion of its aggregate supply curve. As conditions worsened in early 1932, the United States economy entered the Keynesian range, where prices and wages stopped falling and remained stagnant while the unemployment rate reached $24 \%$. It was at this time that many people expected prices and wages to fall, so they started saving more and reduced spending on consumption and investment. However, instead of seeing a rightward shift of the short run aggregate supply, the aggregate demand further decreased with a large reduction in output (Willis, 2017). President Hoover's responses and policies did stimulate a rightward shift of aggregate demand to some extent, but their effects were not persuasive enough to bring the United States economy back to the intermediary range 
of its aggregate supply curve. As a result, the United States economy fluctuated in the Keynesian range until the establishment of Franklin D. Roosevelt's presidency.

If the United States had already moved too far from its previous potential output, what actually ended the Great Depression? In short, President Franklin D. Roosevelt's new economic policies and the arrival of World War II were the main factors that stimulated aggregate demand and brought the United States economy back to the Classical Range of its aggregate supply curve. After achieving a landslide victory against President Hoover in the 1932 presidential election and coming in office on March 4, 1933, President Roosevelt immediately legislated practicable economic policies in combating the Great Depression. Roosevelt created the New Deal, a series of projects and policies that revolved around the "3 R's": relief of the unemployed, recovery of the economy, and reform of the financial institution.

\section{The (Keynesian) Non-Linear Aggregate Supply Curve}

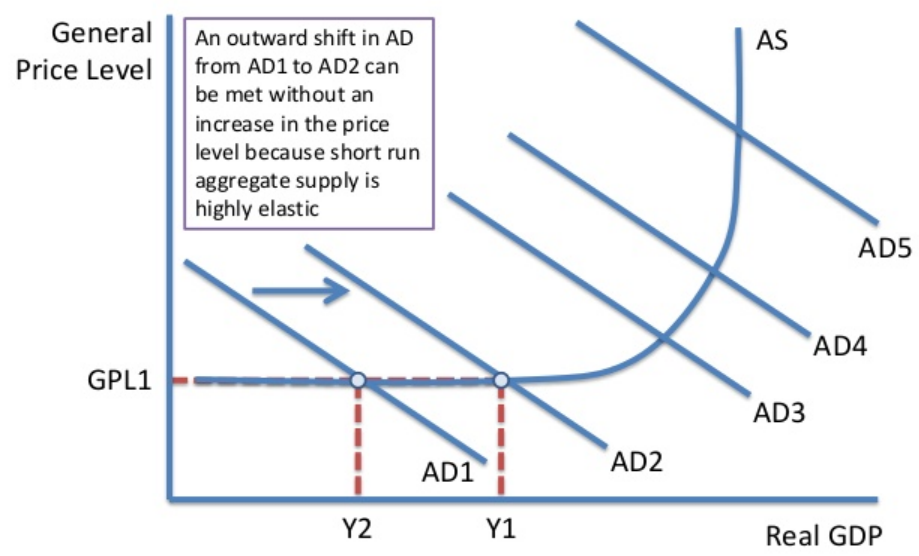

Figure 4: the recovery of the United States economy from AD1 to AD5 observed through the Keynesian Model.

Under Roosevelt's leadership, the United States economy was slow in recovering at first; simply injecting income into the hands of the workers through the Agricultural Adjustment Act and the National Industry Act authorized in early 1935 were not enough to drag the nation out of the depression and aggregate demand remained at AD1 as shown in Figure 4. Nonetheless, President Roosevelt was astute in creating the more aggressive Second New Deal, which enacted the Works Progress Administration and the National Labor Relations Act to offer employment to a large number of the citizens. With the excessive government expenditures on public programs and the unemployment insurance programs, consumers eventually gained purchasing power during when prices and wages were still sticky and static. This stimulated aggregate demand to AD2-as shown in Figure 4-and allowed the United States economy to double its Gross Domestic Product in 1937 from \$47 billion to \$92 billion (Hardman, 1999). By 1940, the United States' unemployment rate had dropped to $14 \%$; the economy observed an unprecedented rate of job creation, especially the massive job opportunities for women, shifting aggregate demand to AD3 as shown in Figure 4. However, the United States suffered from the devastating attack on Pearl Harbor in December 1941, which prompted the nation to enter World War II. While many anticipated that the economy would enter into another recession from the massive damage, the United States became the major exporter to Great Britain and France; \$32.5 billion worth of war goods were exported to the Allied Powers between 1941 to 1945 . World War II allowed the United States economy to enter into the intermediary range of its aggregate supply curve (AD4) and through the increased net exports, the economy ultimately returned to its potential output (AD5) in 1943, when prices and wages were flexible again (Willis, 2017). Altogether, President Roosevelt's New Deal Programs and the onset of World War II allowed for sharp increases in aggregate demand, bringing the United States out of the Great Depression. 
Clearly, Roosevelt's policies were exactly in accordance with Keynes' solutions to economic recessions: to advocate for and conduct expansionary fiscal and monetary policies when the economy failed to correct itself. Expansionary fiscal policy encourages government spending and lowers income tax rates and expansionary monetary policy increases the nation's money supply, which in turn lowers the interest rate and encourages interest-sensitive consumption and investment. Both of these policies are the most essential factors in lifting aggregate demand, which in turn substantially reduces the unemployment rate. In The General Theory of Employment, Interest, and Money, Keynes campaigned for job creation ideas such as "the government should pay people to dig holes in the ground and then fill them up," since "it doesn't matter what [people] do as long as the government is creating jobs." (Keynes, 1936) Although this seems ridiculous, Keynes was trying to emphasize the importance of government spending and the fact that only the government would be willing to spend during a recession. Keynes' innovative analysis of the new macroeconomic policies reminded the world that government and federal reserve interventions are absolutely necessary when an economy is facing sustained problems. Unfortunately, the economy does not always follow the basic foundation of the Invisible Hand; Keynes' effort in ratifying the role of the government and federal reserve in the economy has brought many long-lasting impacts and transformed the ways economists view severe recessions in the modern world. As such, Keynes reminded the American population that:

"If you owe your bank a hundred pounds, you have a problem. But if you owe a million, it has" (Keynes, 1936).

\section{Phillips Curve}

Although Keynesianism generally favors any sort of interventions to control the economy under devastating circumstances, Keynes was more of a direct supporter of fiscal policy over monetary policy. Keynes believed that fiscal policy, especially controlling government expenditures, has a direct influence on aggregate demand. Monetary policy, on the other hand, only changes the money supply and the interest rate at first, which would then influence consumer decisions and eventually change aggregate demand. This process, according to Keynes, takes a significant amount of time, shatters the confidence of many investors, and leaves no difference when the interest rate is already low. This "Liquidity Trap Phenomenon" was evidenced again in the Great Depression: increased savings, low investment confidence, and low interest rates as a result of the stock market crashes of 1929 did not prompt the American population to engage in capital investment. Fiscal policy, on the other hand, has nothing to do with individual decision-making and thus proved to be effective in the Great Depression.

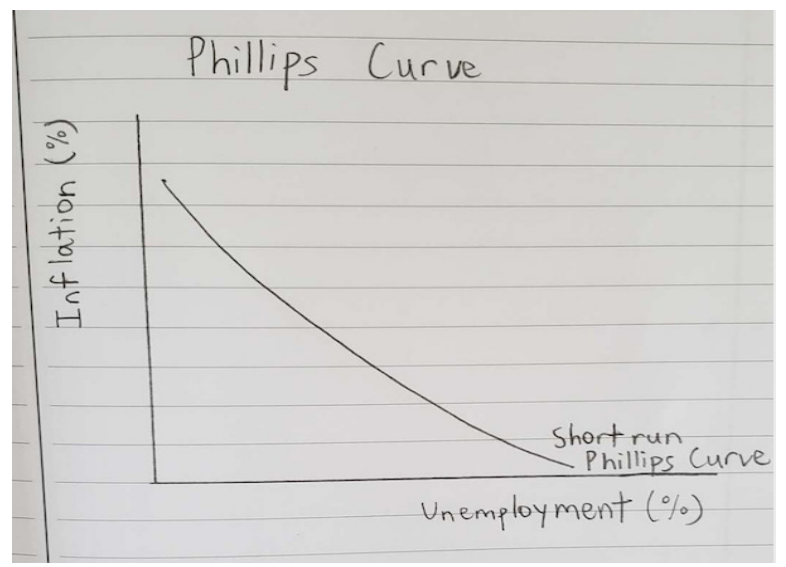

Figure 5: the Phillips Curve illustrates that there is a tradeoff between inflation and unemployment.

It is often burdensome in determining which policy is more effective over the other and many economists today have conceded that implementing a combination of both would often maximize the benefits provided to the economy. After 
the events of World War II, many economists rejected the classical theory and became avid supporters of Keynesianism. Building on his theory, British economist William Phillips advanced a new economic model known as the Phillips Curve in the late 1950's through his book The Relation between Unemployment and the Rate of Change of Money Wage Rates in the United Kingdom. The Phillips Curve, shown above in Figure 5, can be conceptualized in that there exists a negative correlation between inflation and unemployment in the short run, which was clearly shown in the Great Depression when high levels of unemployment were accompanied by deflation of prices and wages.

Nonetheless, as time progressed to the early 1970s, the United States suddenly began observing unprecedented levels of inflation, reaching double digits by 1974 and levels as high as $13.5 \%$ in 1980. According to the classical economic theory, an economy would be experiencing high levels of inflation if it is producing beyond its potential output, indicating that the economy must be doing exceptionally well and experiencing long run economic growth. However, this was not exactly the case in the United States; rather, the economy suffered from cost push inflation - constant leftward shift of the short run aggregate supply curve largely due to increases in oil prices. At this time, supporters of Keynes and Phillips supposed that the economy would be experiencing lower levels of unemployment under high levels of inflation, but this was again, not the case, and the national unemployment rate rose to $8.5 \%$ in 1975 and a stunning 9.7\% in 1982, during times when inflation was also high (Nielson, 2020, Stagflation in the 1970s). This severe stagflation phenomenon could no longer be explained by William Phillips' theory, and the United States found itself in another economic crisis. Like the Great Depression, this crisis has led to another reevaluation of macroeconomic policy.

\section{Monetarism}

As the United States experienced "The Great Inflation" of the 1970's, American Economist Milton Friedman rose to prominence with his theory that supports controlling the nation's money supply to reduce inflation. Monetarism is often recognized as utilizing monetary policy, that is, the Federal Reserve's actions of controlling the growth rate of the money supply to regulate the economy. Collaborating with Anna Schwartz in 1963, Friedman composed his book A Monetary History of the United States, 1867-1960, in which he argued that "the central bank of the world's economically most important nation in 1929 was essentially leaderless and lacking in expertise" (Friedman \& Schwartz, 1963), challenging Keynes' believe that the main cause of the Great Depression was a lack of government spending. Friedman believed that the Federal Reserve had much a greater influence on the United States economy than what was previously thought: the misguided target growth rate of the money supply resulted in markets behaving erratically, causing the sudden stock market crash in 1929.

\section{$M V=P Y$}

Figure 6: The Quantity Theory of Money (Irving Fisher Equation)

Monetarism is founded by the Quantity Theory of Money (shown in Figure 6 above), an equation established by classical economist Irving Fisher in the 1920s that shows that an economy's "money supply multiplied by velocity (the rate at which money changes hands) equals nominal expenditures in the economy (the number of goods and services sold multiplied by the average price paid for them)" (Jahan \& Papageorgiou, 2014).

The classical economists argued through the Say's Law that in the long run, the velocity of money and the total output in the economy would remain relatively static; the economy would produce at its potential output while maintaining a stagnant flow of money. This suggests that increasing the money supply will only result in a proportional increase in the price level, leading to severe levels of inflation instead of steady economic growth. Friedman was able 
to use the Quantity Theory of Money to criticize the validity of the Phillips Curve in 1968: in the long run, the Phillips Curve is not an accurate reflection of the economy as there seems to be no relationship between inflation and unemployment.

Moreover, Friedman used the Quantity Theory of Money to argue against Keynes' fiscal policy and his statement that "money does not matter." The Keynesians accentuate the efficacy of the "multiplier effect" when fiscal policy is used. The multiplier effect suggests that initial government expenditure results in "increases in private spending that additionally stimulates the economy" since these expenditures would go directly to the incomes of the consumers (Silver, Kagan \& Frankenfield, 2020).

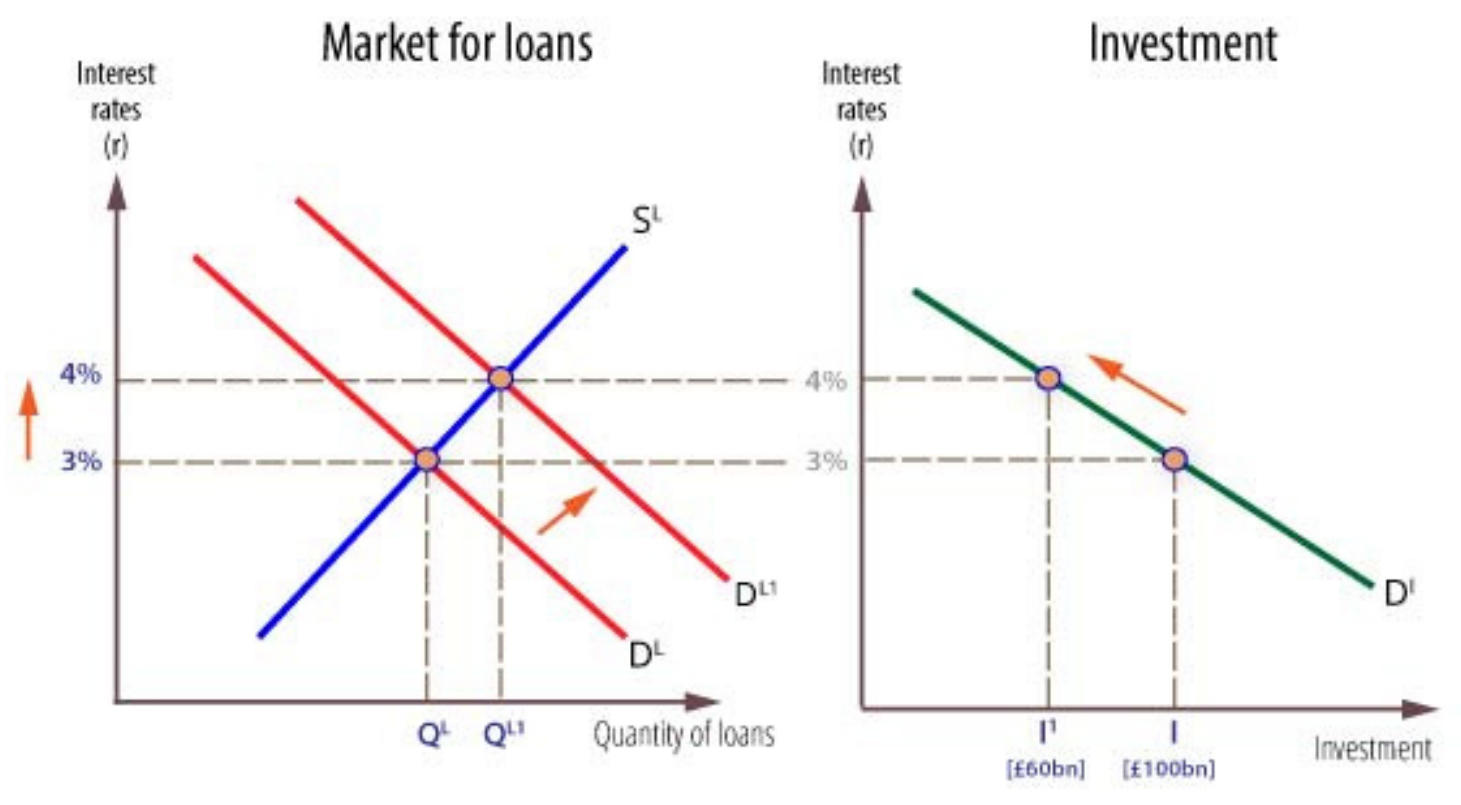

Figure 7: Government borrowing increases the demand for loanable funds and thus the interest rate, causing a reduction in the quantity of desired investment, depicting the crowding out effect.

However, Friedman and the Monetarists were not assured that the multiplier effect is the only consequence of fiscal policy. Essentially, Keynes had somewhat neglected the importance of interest rate to the economy, and most importantly, the consequences of deficit spending by the government. During times of severe economic conditions, governments cannot rely on tax revenues to facilitate their intentions of spending. As a result, governments play a key role in borrowing from the available supply of loanable funds from the private sector to undergo severe deficit spending to stimulate aggregate demand. According to the classical economic theory, the amount of loans in an economy is the sole determinant of interest rate. Consistent borrowing from the government would increase the demand for loanable funds, shown in Figure 7 above. As the government's demand for loans increases, less loans will be available to individuals, aggrandizing the interest rate and decreasing the amount of desired investment (I to I'). This is a reflection of the "crowding out effect," in which the increased interest rate from government borrowing makes it burdensome for individuals to commit to capital investment and consumption (Silver et al., 2020). This phenomenon would counteract the effects of government spending, since government spending may occur simultaneously with reductions in investment spending.

As Keynesianism fell out of popularity with policymakers, the United States economy was left stranded and it was entirely up to the monetarists to resolve the effects of stagflation. As a contractionary monetary policy is mainly 
used to control the rate of inflation, the monetarists realized that to stabilize the economy, inflation should be first controlled, even if "it temporarily causes a disruption to economic activity and, for a time, a higher rate of joblessness." If we never get rid of the problem of inflation, prices and wages will continue to rise, causing inevitable rises in the unemployment rate. In 1979, Paul A. Volcker took over as the chair of the Federal Reserve Board, where he enacted policies in favor of monetarism to the unprecedented levels of inflation. Through Volcker's efforts, the Monetary Control Act of 1980 was established and throughout the next few years, the United States economy began to observe significant increases in the federal funds rate and contraction of the money supply. Lending activities fell to its lowest and the national unemployment rate rose to $10.8 \%$ in 1982 (Bryan, 2013). However, the economic policies enacted to reduce inflation were successful; the United States was able to obtain an inflation rate of 3.21\% in early 1983. "The Great Inflation" ended and through policies such as the Economic Recovery Tax Act of 1981, the United States economy was able to leave the recessionary gap in late 1982.

Assuredly, Friedman's emphasis on monetary policy opened new doors in the history of macroeconomic theory. Economists have come to the full understanding that a commitment to price stability is essential for maximizing employment while attaining stable economic growth. But monetarism has its own drawbacks, and the attempt to discard Keynesianism in the 1970s proved problematic. As time progressed to the 2000s, the United States economy encountered its most recent major economic meltdown: The Great Recession of 2008. This major recession followed after the 2006 Subprime Mortgage Crisis. In the early 2000s, the United States economy was facing stable economic growth and low interest rates. These low interest rates allowed people who would normally never have been able to purchase a home to become homeowners. As a result, housing prices rose drastically from the rising demand of borrowers. To compensate for the rise in demand, the Federal Reserve kept interest rates low and did not adjust the money supply This was a tremendous risk, since the low interest rate allowed lenders to approve lending to subprime borrowers or those who lacked creditworthiness. The mortgage brokers then took advantage of the low interest rates and the constant demand for loans. (Amadeo, 2020, The Great Recession of 2008).

The Bush Administration and the Federal Reserve believed that the over reliance on derivatives was not a problem as long as money supply is growing consistently with low interest rates. While the Federal Reserve ignored potential warnings from the Commerce Department in late 2006 about declining housing permits, many speculative investors had already stopped giving out loans due to the high risk. This caused housing prices to suddenly decrease, crashing the housing market and increasing the amount of foreclosures. In April of 2007, the Federal Reserve attempted to resolve its over reliance on derivatives through encouraging lenders to make loan arrangements (Nielson, 2020, Why Housing Market Bubbles Pop). However, this was not enough to conquer the Subprime Mortgage Crisis, and the housing crisis soon created a Domino Effect that affected the entire economy.

The situation quickly worsened and somewhat modeled the Great Depression in that many borrowers struggled to pay back to lenders. As predicted, the stock market finally crashed on September 29, 2008, shifting the United States economy into a major recessionary gap. The Federal Reserve took the full blame for this economic crisis; it overlooked many warnings from investors and underestimated the high risks associated with mortgages. Luckily, the government responded quicker to this recession than it did in the early 1930s. On October 3, 2008, the Congress authorized the Troubled Asset Relief Program, a $\$ 700$ billion support from the federal government that aimed to inject capital into many of the failing banks. Moreover, newly elected President Barack Obama established a \$787 billion economic stimulus to recover the economy; $\$ 282$ billion served as tax cuts and $\$ 505$ billion were government expenditures that assembled new healthcare systems, education, and projects. Eventually, this major stimulus ended the Great Recession of 2008; although the unemployment rate lingered around $10 \%$, the effects of the urgent fiscal policy allowed the economy to return to its potential after June of 2009 (Amadeo, 2020, The Great Recession of 2008).

The Great Recession of 2008 manifested the fragility of the monetary system and the poor decision-making of the Federal Reserve. Monetary policy failed to predict the consequences of excessive lending, not to mention the Federal Reserve's lack of response to control the money supply and federal funds rate during the peak of this recession. The Great Recession of 2008 was profound in that it proved to economists that Keynesianism is still relevant and should not be abandoned altogether. Undoubtedly, Friedman's arguments on Monetarism are applicable to many 
situations, but the United States would not have gotten out of the recession if the government did not implement the two stages of expansionary fiscal policy. Ultimately, the Keynesian approach resolved the nation's second most significant economic crisis, once again proving that fiscal policy has more of a direct influence on aggregate demand.

\section{Conclusion}

The evolution of modern macroeconomic theories has transformed our understanding of how policymakers manage the economy during times of economic crises. From the works of economists John Maynard Keynes, William Phillips, and Milton Friedman, we can conclude that it is no longer valid to trust the Invisible Hand under harsh economic conditions. The classical economists severely underestimated the scope of the Great Depression and established models that were too simple to be explained in the complicated world. Although the debate between whether we should follow Keynesianism or Monetarism is still prevalent, it is without doubt that both economic theories have their strengths and drawbacks. Keynesianism and the enactment of fiscal policy have been successful during major economic recessions; as consumer confidence falls to its lowest, the liquidity trap dilemma arises. Even if interest rates are lowered, the public would still prefer to hold cash rather than to hold debt since investment is risky during economic downturns. Therefore, the government is the only institution that would be spending money to stimulate aggregate demand. Fiscal policy, however, has proven ineffective in circumstances in which government deficit spending causes the Crowding Out Effect, which would counteract the intended effects of fiscal policy. On the other hand, monetarism and the actions taken by the Federal Reserve were effective during times of great inflation and slow economic growth. Managing the money supply is crucial; the Federal Reserve's actions to target interest rates and change the federal funds rate have resulted in price stability and reductions in inflation.

Ultimately, the central problem in modern macroeconomy is not whether one policy is superior over the other. The implementation of both fiscal and monetary policy is regularly observed during short run business cycle fluctuations in the economy and are crucial for future economic growth. The most important thing for policymakers is to know when to use each policy and not to wholly favor one over the other. If policymakers are able to make the right decision and predict outcomes that would cause the least harm to the vast majority, then we would be able to prevent catastrophes like the Great Depression from happening again.

No one knows for sure what lies in the future for the macroeconomic world. But one thing is certain: we can no longer rely on the classical economic model and expect prices and wages to always adjust to current economic circumstances. We should continue to advocate for active fiscal and monetary policies during times of economic hardships to prevent future economic crises. As the old saying from President Theodore Roosevelt suggests, "in any moment of decision, the best thing you can do is the right thing, the next best thing is the wrong thing, and the worst thing you can do is nothing."

\section{References}

Amadeo, K. (2020, April 12). Great Depression Timeline. Retrieved June/July, 2020, from https://www.thebalance.com/great-depression-timeline-1929-1941-4048064

Amadeo, K. (2020, July 01). The Great Recession of 2008: What Happened, and When? Retrieved July 25, 2020, from https://www.thebalance.com/the-great-recession-of-2008-explanation-with-dates-4056832

Bryan, M. (2013, November 22). The Great Inflation. Retrieved July 20, 2020, from https://www.federalreservehistory.org/essays/great inflation 
Corbett, P., Janssen, V., Lund, J. M., Pfannestiel, T., \& Waskiewicz, S. (2014, December 30). US History II (OS Collection). Retrieved June 27, 2020, from https://courses.lumenlearning.com/suny-ushistory2os2xmaster/chapter/president-hoovers-response/

Friedman, M., \& Schwartz, A. J. (1963). A Monetary History of the United States, 1867-1960. Princeton, NJ: Princeton University Press.

Hardman, J. (1999, July 26). The Great Depression and the New Deal. Retrieved July 23, 2020, from https://web.stanford.edu/class/e297c/poverty prejudice/soc sec/hgreat.htm

Jahan, S., \& Papageorgiou, C. (2014). What is Monetarism? FINANCE \& DEVELOPMENT, 51(1). Retrieved June/July, 2020, from https://www.imf.org/external/pubs/ft/fandd/2014/03/basics.htm

Kenton, W. (2020, January 24). Learn About Aggregate Supply. Retrieved June/July, 2020, from https://www.investopedia.com/terms/a/aggregatesupply.asp

Kenton, W. (2018, April 29). What Is the Sticky Wage Theory? Retrieved June/July, 2020, from https://www.investopedia.com/terms/s/sticky-wage-theory.asp

Keynes, J. M. (1936). The general theory of employment interest and money. Palgrave Macmillan.

Kilcoyne, M. (2019, August 13). The consumer is at the heart of all production. Retrieved July 28, 2020, from https://www.ft.com/content/4f30346a-bdbb-11e9-89e2-41e555e96722

Lee, J. (2008, October 14). New York and the Panic of 1873. Retrieved July 29, 2020, from https://cityroom.blogs.nytimes.com/2008/10/14/learning-lessons-from-the-panic-of-1873/

Majaski, C. (2020, January 29). Dispelling Mysteries About the Invisible Hand. Retrieved June 25, 2020, from https://www.investopedia.com/terms/i/invisiblehand.asp

Nielsen, B. (2020, April 04). Stagflation in the 1970s. Retrieved July 15, 2020, from https://www.investopedia.com/articles/economics/08/1970-stagflation.asp

Nielsen, B. (2020, January 29). Why Housing Market Bubbles Pop. Retrieved July 26, 2020, from https://www.investopedia.com/articles/07/housing bubble.asp

Onion, A., Sullivan, M., \& Mullen, M. (2020, February 29). Great Depression History. Retrieved June 22, 2020, from https://www.history.com/topics/great-depression/great-depression-history

Onion, A., Sullivan, M., \& Mullen, M. (2020, February 29). New Deal. Retrieved June/July, 2020, from https://www.history.com/topics/great-depression/new-deal

Pells, R., \& Romer, C. (2020, May 18). Great Depression. Retrieved June 22, 2020, from https://www.britannica.com/event/Great-Depression 
Pettinger, T., Samuel, A., Gichana, J., Waqas, M., McCray, A., Anyam, B., . . Nomzamo. (2019, November 25). Keynesian vs Classical models and policies. Retrieved June 26, 2020, from https://www.economicshelp.org/keynesian-vs-classical-models-and-policies/

Silver, C., Kagan, J., \& Frankenfield, J. (2020, July 13). Crowding-Out and Multiplier Effect Theories of Government Stimulus. Retrieved June/July, 2020, from https://www.investopedia.com/ask/answers/060915/how-doescrowding-out-effect-influence-multiplier-effect-government-stimulus.asp

Willis, B. (Producer). (2017, September 1). Macro: Unit 2.6 -- Classical v. Keynesian Theories [Video file]. Retrieved June/July, 2020, from https://www.youtube.com/watch?v=xXNrloLHOzI

Young, J. (2020, January 29). Classical Economics and the Evolutions of Capitalism. Retrieved July 02, 2020, from https://www.investopedia.com/terms/c/classicaleconomics.asp 